\title{
"Discourses of Displacement" in the Ethnography of Léon-Gontran Damas and Poetry of Charles Baudelaire
}

\section{Michael Reyes Salas}

Numéro 116, été 2020

Dossier spécial Léon-Gontran Damas

URI : https://id.erudit.org/iderudit/1071043ar

DOI : https://doi.org/10.7202/1071043ar

Aller au sommaire du numéro

Éditeur(s)

Department of French, Dalhousie University

ISSN

0711-8813 (imprimé)

2562-8704 (numérique)

Découvrir la revue

\section{Citer cet article}

Reyes Salas, M. (2020). "Discourses of Displacement” in the Ethnography of Léon-Gontran Damas and Poetry of Charles Baudelaire. Dalhousie French Studies, (116), 43-56. https://doi.org/10.7202/1071043ar
Résumé de l'article

Il n'est pas irréaliste d'imaginer que la sous-classe qui occupait les voies urbaines que Charles Baudelaire parcourut comme flâneur, aurait pu être envoyée au bagne décrit par le poète de la Négritude Léon Damas dans son travail ethnographique en Guyane. À travers une lecture attentive de l'ethnographie et essai anticolonialiste, Retour de Guyane (1938), en tandem avec quelques poèmes en prose du Spleen de Paris (1869) et des Fleurs du mal (1857) de Baudelaire, cet article souhaite illustrer les parallèles entre les méthodes d'observation qu'ils utilisent pour collectionner les études de cas qui figurent dans leurs oeuvres. L'approche interprétative que j'utilise reconnaît le croisement entre la créativité littéraire et l'analyse sociologique et est informée par un cadre théorique qui couple l'anticolonialisme de la Négritude avec les études carcérales. Mon analyse de ces textes est située dans le contexte des lois de la troisième République contre la récidive et le vagabondage, qui prévoyaient la peine de la déportation dans des bagnes lointains, une pratique punitive qui a continuée jusqu'au début du vingtième siècle. Dans le cas de Baudelaire, les changements de la situation sociopolitique survenus à la suite de l'hausmannisation, ont rendu nécessaire pour les écrivains de trouver de nouveaux modes de configurer le développement exclusif de la ville capitale. Dans le cas de Damas, sa critique de la mise en valeur et des études coloniales fondées sur l'exploitation l'ont incité à abandonner les pratiques conventionnelles de l'ethnographie de sauvetage, qui simule une inclusion objective. Cet article se concentre sur des passages textuels qui soulignent les liens entre les attributs coloniaux et carcéraux dans la colonie et dans la métropole. En conclusion, je soutiens que la condamnation de la mission civilisatrice faite par Damas en tandem avec la contestation de la dégradation de l'environnement urbain faite par Baudelaire, nous orientent vers une poétique de l'ivresse du pouvoir absolu de la société coloniale.
Ce document est protégé par la loi sur le droit d'auteur. L’utilisation des services d’Érudit (y compris la reproduction) est assujettie à sa politique d'utilisation que vous pouvez consulter en ligne.

https://apropos.erudit.org/fr/usagers/politique-dutilisation/ 


\title{
"Discourses of Displacement" in the Ethnography of Léon-Gontran Damas and Poetry of Charles Baudelaire
}

\author{
Michael Reyes Salas
}

\section{Introduction: All that Glitters}

? $t$ is not far-fetched to imagine that the French underclass that occupied the city streets Charles Baudelaire roamed as a flâneur, could have turned up in the bagne, or penal colony, described by Léon-Gontran Damas during his ethnographic field work in his pays natal. While primarily serving to maximize private profit, the widespread infrastructural development in France and its overseas territories, from the Haussmannization of midnineteenth-century Paris to the perfunctory mise en valeur of Guyane in the early twentieth century, also aimed to exercise control over social outcasts (Davis 98). ${ }^{1}$ One method of managing the surplus population enacted by the government of the French Third Republic was to create laws against recidivism and vagrancy in the late nineteenth-century, which carried the penalty of forced deportation to distant penal colonies such as Guyane. Between 1851 and 1881, the number of people deported to penal colonies for recidivism and vagabondage increased by an unprecedented $233 \%$ (Sanchez 76 ). This period coincides with profound changes in the urban environment of Paris during which the issue of overcrowding became reflected in literature of the era. However, a potentially overlapping cast of background characters within the descriptive writings of these authors is not the only link Damas and Baudelaire have in common.

In contrast to comparisons between these authors which focus exclusively on their poetic writing, I examine Léon Damas's ethnographic writing in tandem with prose poems by Charles Baudelaire through their mutual thematization of development, exploitation, inclusion, and exclusion. In a 1971 interview with Jeune Afrique titled "La Négritude en question," Damas admits to having been influenced by the work of Baudelaire. The point of this essay is not to prove that Baudelaire influenced Damas. Instead, Damas's candid admission gives rise to a compelling thematic and methodological comparison between a quintessential modern French poet and Negritude intellectual.

From the outset, Léon-Gontran Damas's ethnography, Retour de Guyane (1938), foregrounds the history of Guyane by referencing early colonial ventures fueled by the myth of El Dorado. By addressing this myth, the richness of Guyane's land is discussed throughout the text as Damas alludes to the various abundant mineral resources the land possesses and the hyperfertility of the soil. Although gold had been extracted from French soil in meager quantities since the time of the Gauls, the mineral extraction industry intensified after the late nineteenth-century as the existence of gold deposits in Guyane was confirmed in 1855 (Taubira-Delannon). Damas is not against mineral extraction in and of itself, as he explains towards the end of the text: "Il faudrait organiser une exploitation rationnelle des gisements aurifères de la Guyane [...] cette exploitation, convenablement dirigée, entrainerait par son existence même l'exploitation d'à peu près toute la vie industrielle et commerciale du pays" (151). Instead, Damas urges an approach to gold extraction that is not purely exploitive and is considerate of mineral finitude. This environmental concern reveals awareness of how industrial relations premised on extractive approaches eventually result in the predatory desire to conquer.

1 Following the example of Wood and MacLeod 4, I avoid reference to 'French Guianese' as well as 'French Guiana'. 
Beyond interest in searching for the mythical riches of El Dorado, extractive practices expose settler attitudes of entitlement to land. An impactful instance of such environmental valorization is evident when Damas mentions the grand error committed by reputed French abolitionist Victor Schœlcher, which was to "émanciper les esclaves sans émanciper la terre" (152). The Negritude writer's critique of Schœlcher, which indicates an underlying post-abolition subjugation of the land, reflects an attribute of partial emancipation described by Gary Wilder, who argues that: "political rights without radical social transformation is a recipe for continued colonial dependence" (229). In lieu of exploiting the resource of black labor in plantation style economies, international mining companies reinforce land dispossession as they exploit natural resources, of which they are the primary beneficiaries, and consequently keep intact the socioeconomic stagnation of Guyane. In addition to the colonial fantasy of El Dorado, Retour de Guyane focuses on several other instances of administrative negligence which highlight an exploitative impulse that shows little to no concern about the creation of harmful environmental conditions. The desire for Guyane's gold in the French colonial imaginary, and the attendant conquest of land containing mineral deposits brings to the fore a profound situational irony: colonial subjects are often targets of bourgeois intolerance despite the fact that many bourgeois luxuries, such as gold, commonly derive from colonized regions.

The "colony-metropole" model of cultural traffic that has been used to frame the relation of Guyane and Paris offers a vantage point from which to identify procedures of social exclusion, what Mike Davis calls the removal of "human encumberments," applied towards colonial subjects as well as marginalized groups of the urban metropole (98). ${ }^{2}$ A prose poem from Baudelaire's Spleen de Paris (1869) entitled "Les yeux des pauvres," captures the divide between the haves and have nots of Paris, concisely depicting bourgeois callousness towards poverty. It takes place in the Haussmann era at a brand-new café at the corner of a newly built boulevard. As a man and woman enjoy an evening on the café terrace, a middle-aged father and his two boys in tattered rags are huddled on the sidewalk before them. The poor family gazes at the café:

Les yeux du père disaient : "Que c'est beau ! Que c'est beau ! On dirait que tout l'or du pauvre monde est venu se porter sur ces murs." - Les yeux du petit garçon : "Que c'est beau ... mais c'est une maison ou peuvent seuls entrer les gens qui ne sont pas comme nous" . . Non seulement j'étais attendri par cette famille d'yeux, mais je me sentais un peu honteux de nos verres et de nos carafes, plus grands que notre soif (84-85).

The bourgeois narrator reacts to the gaze of the poor family by being ashamed of his abundance as he has more than enough drink to quench his thirst, while the father and the boys can only watch with impossible desire. As food accessibility is evidently unequal across class boundaries, rather than being proud of possessing abundance, the poem's narrator feels guilty for having a safe food and water supply. The poor youth demonstrates an understanding of the beautified new space's exclusivity. Well aware that poor people are not meant to enter the café, the boy comprehends the nuances of social taboos which reinforce class divides in the new space relations of the redeveloped city. While guessing what the poor father ponders as he gazes in awe at the building's opulence, the prose poem's privileged narrator interpolates the thought that the poor man likens such brilliance to "tout l'or du pauvre monde" (Baudelaire 84). The narrator's speculative remark implies that colonial spoils, such as gold, have financed the urban splendor of Paris. At the closing of "Les yeux des pauvres," the male bourgeois narrator looks into the eyes of his female companion for her response, anticipating her affirmation of sympathy; instead, she looks at the poor with disgust and demands that he tell the waiter to make the family leave. As

2 On challenging the "center-periphery" framework, see Kellman 1-11. 
Baudelaire demonstrates the extreme class prejudice that policed the newly developed urban space, he chooses to gender the insensibility as "feminine," as the man feels alienated from the woman with whom he is dining (135). The bourgeois woman affirms what the street youth intuited: the poor are sacrificed at the altar of urban modernity.

Literary critic Stephen Walton has previously acknowledged Baudelaire's impact on Negritude by pointing out that: "while the poetic transformation of spleen, of ennui, of a rotting corpse, may not have any apparent political significance, the elevation of the abject is inherently subversive because it implicitly challenges the social forces that determine literary conventions" (79). The ability to perceive and revalorize that which is considered worthless is indicative of a willingness to resist the prevailing episteme. In a brief essay Richard Djiropo explores the overlap in Baudelaire's Fleurs du mal (1857) and Damas's writing by pointing out how each poet recognizes the links between "peine personelle" and "histoire collective" (Djiropo 137). Building on Djiropo's observation, I contend that Baudelaire and Damas's respective abilities to partake in collective imagination are linked to the observational methods they use to collect case studies for their writing. This essay calls renewed attention to Damas-Baudelaire comparisons by evaluating how the distinct scopic regimes they enact on their respective environments, as flâneur and ethnographer, connect personal pleasures and pains to a broader sociohistorical context.

\section{Le flâneur et "ethnographe atypique": Sociological Analysis and Literary Creativity}

At first glance the approaches Baudelaire and Damas use to survey their respective urban environments, flânerie and ethnography, may appear to have little in common. Yet, ethnographers today have increasingly acknowledged the importance of flânerie as a precursor and informative tool to modern practices of carefully studying metropolitan spaces. The flâneur's practice of urban spectatorship, which takes place in solitude amidst the multitude, served to observe the fleeting nineteenth-century Parisian cityscape in what Walter Benjamin describes as the era of high capitalism. By virtue of his street-wandering at a leisurely pace, out of sync with the busy inhabitants of the capital city, the flaneur was often cast as an idle loiterer. Contrastingly, the assumption of such a disposition has been read by some sociologists as "a form of resistance against a booming, and engulfing, social economic system" (Jenks and Neves 4). Upon reading Baudelaire's numerous poems, which are often comprised of observations made during flanerie, it becomes clear how the practice's deep investment in "recording and interpreting the fragmented, fleeting moments of urbanites - their movement in architecture and city structures" lends itself to comparison with ethnographic methodology (Soukup 239). Reading Baudelaire's poetry and Damas's ethnography together, I refer to the work of Priscilla Parkhurst Ferguson, who writes about interpretive frameworks that "fuse the imaginative mode of literature and the analytical method of social science" (107), as a model for exploring how these poet-authors stress the ironies of urban and colonial development.

In the 1930s, when Damas was pursuing his studies in Paris, ethnography as a methodology of the social sciences was in its nascent phase. The eurocentrism that marked earlier ethnography gradually transformed as racist pseudoscience in the guise of scientific practice became dispelled. The ongoing task of debunking such entrenched racism was addressed early on by Damas. Writing during a time in which colonial subjects of the French Empire were characterized by Arthur de Gobineau and Lucien Lévy-Bruhl as primitive savages who possessed a dependency complex, Damas was up against discursive regimes that sought to justify colonialism. In her essay "Léon-Gontran Damas et le mythe de l'Amérindien," Kathleen Gyssels clarifies how "Damas s'oppose catégoriquement à tout un lexique ethnologique qui consiste à ramener l'Autre à une catégorie 'inférieure"" (47). The fact that Damas challenged the prevailing academic norms of his time indicates that he was an "ethnographe atypique" (Gyssels 20). 
As a mise en valeur culture began to sweep the field of French anthropology, attributing value to colonized civilizations to compensate for their prior devaluation, pioneering ethnologists who founded The Institute of Ethnology in Paris began actively recruiting African and Antillean students into the certificate program. ${ }^{3}$ These efforts at diversifying the academy were part of a broader national project of assimilation. The recruitment of students native to colonized societies marked an effort to collect new colonial scholarship from 'native informants.' In this context, becoming acclimated to the process of conducting fieldwork in the colonies, returning to the metropole and ultimately publishing studies was a rite of passage for becoming a colonial administrator. Damas was strongly opposed to such a program of assimilation that stifled the self-expression of Afrodescendent peoples. In Retour, he claims that because France's mission civilisatrice viewed assimilation as an act of reparation, an amelioration, colonized subjects of France should not assimilate into the nation since such complicity would confirm the existence of a deficiency (129). While Damas was drawn to ethnology he resisted the underlying expectation of committing to a lifelong role as a state functionary and instead drew from the anthropological tools it offered him to partake in cultural critique. ${ }^{4}$

While completing his certificate program at The Institute of Ethnology, Damas was assigned by his advisors to research Afro-Amerindian maroon communities in the Amazon rainforest, known as the nègres bosh (bush Negros), in his native Guyane. Damas's project was to be incorporated in a museum exposition on the theme of marronage, a form of slave escape, entitled: "Africa in America" (Debaene 358). Since the assignment corresponded with Damas's research interests, he accepted the task. Shortly after arriving in the field to commence his ethnographic project, Damas began to deviate from the original plan, partially due to the fact that the planned museum exhibition was abandoned. Yet aside from the circumstantial reasons, Damas also chose to go against the "mise en valeur" ethnographic standard that was expected of him-objectively documenting the nègres bosh - by instead choosing to write about the urgent crisis regarding the violent practices of Guyane's colonial administration.

Damas's production of Retour, a text that counters the dominant conventional outlook of his academic discipline, marked a rebellious act of self-representation. Such outstanding textual attributes have led F. Bart Miller to classify the text as a hybrid of ethnography and anticolonial essay. According to Miller, through a "creative interpellation of ethnographic observation... combined with essayistic commentary," Damas adapts "the form of the ethnographic narrative... in order to undermine its supposed purpose of promoting colonialism" (142). By foregrounding the role of multigenre literature and writinganother aspect Damas shares with Baudelaire-Miller's observation serves as a point of departure into interdisciplinary questions which lie at the crux of sociological analysis and literary creativity.

At the same time that Miller describes Damas's essay-ethnography as making "no attempt to hide his bias towards his subject matter in his discourse" he also frames it as an example of writing at the crossroads of "subjectivity" and "objectivity" $(115,140)$. This conflicted aspect of Miller's reading is indicative of how Damas's personal encounters with colonialism cannot be rendered 'objectively.' While ethnography has historically operated with the imperative of training researchers to produce so-called unbiased knowledge, current scholarship has aimed to undo the binary subjective/objective model by seeking out intersubjective frameworks. ${ }^{5}$ It merits acknowledging that Damas's multigenre writing anticipates the critical self-reflective ethnographies, autoethnographic work and testimonio

3 On mis en valeur practices, see Aldrich 923-4.

4 For context on Léon-Gontran Damas's involvement in the French National Assembly (1948-1951), see Gyssels, 2003.

5 See Pels 211-236 
genres of the later twentieth century which aim to "challenge objectivity by situating the individual in communion with a collective experience marked by marginalization, oppression, or resistance" (Bernal et al. 363). Demonstrating awareness of the shortcomings and blind spots inherent in the historical construct of anthropological objectivity necessitates an acknowledgement that although many ethnographies are presumed to be objective - or presumed to have the capability of being objective - the disciplinary practice is always influenced by the subjectivity of the ethnographer.

In the introduction of Steven Feld and Keith Basso's anthology Senses of Place, ethnographic texts are identified as those that "describe and interpret some of the ways in which people encounter places, perceive them, and invest them with significance" (8). In order to examine how people engage with their environment, Feld and Basso emphasize how place is space endowed with meaning. As the title of their anthology suggests, they highlight how ethnographers gain senses of place via "the relation of sensation to emplacement: the experiential and expressive ways places are known, imagined, yearned for, held, remembered, voiced, lived contested and struggled over; and the multiple ways places are metonymically and metaphorically tied to identities" (11). From such a vantage point, ethnography is premised on our capacities to affect our environments and to be affected by them as the practice informs us about ourselves and how we to relate to places. This lens that ties sense and place to identity formation can also serve to better understand how emplacement is tied to the projects of nation-building and settler colonialism.

Damas challenged colonial scholarship, and its exoticized typologies, by making a political intervention which he deemed more urgent than the documentation of the nègres bosh. The drive for ethnologists to document native communities in the early twentiethcentury was tied to the prevailing idea that indigenous peoples and their lifeways were on the brink of extinction, and soon to be sacrificed at the altar of urban modernity. As the European settler colonialist land-grab in the Americas devastated numerous indigenous communities, subsequent displacement and genocide gave many settlers during the later nineteenth and early twentieth century the impression that autochthonous communities would eventually disappear. The impetus to preserve 'vanishing cultures,' part and parcel of the mise en valeur doctrine, resulted in the practice of salvage ethnography. Current studies are reaching the conclusion that those who prescribed to the "extinction narrative" couldn't have been more wrong (Hochman xii). In many cases, survivance has prevailed in the communities that were perceived by anthropologists to be on the brink of extinction as indigenous communities have used media to their advantage by documenting cultural practices on their own terms. Borrowing the term from Ojibwe scholar Gerald Vizenor for this Guyanais context, Native survivance is "an active sense of presence over absence, deracination, and oblivion . . . the continuance of stories, not a mere reaction, however pertinent" (1). Unlike mere survival, survivance entails an active and sustained storytelling tradition. As a member of a marginalized community of Afro-Amerindian descent, LéonGontran Damas uses the preservationist methodology of ethnography in a counterdiscursive manner in the name of survivance.

The perils of extinction brought on by urban modernity's spread in the colonies are analogous to the exclusionary contours of urban development in the metropole. Throughout the mid-nineteenth century the population of Paris increased in size exponentially as rural migrants arrived in the city in search of work. It soon became clear that the city required large-scale construction to accommodate the growing demographics. In efforts to address these issues, the emperor Louis-Napoleon Bonaparte inaugurated a series of urban redevelopment projects. The reorganization of the transport and communication systems resulted in the formation of new space relations. Shortly after the declaration of empire by Louis-Napoleon, Baron Georges Eugène Haussmann, an elite public administrator, was appointed prefect of the Seine and was mandated to spearhead the redevelopment of Paris. As the city was reshaped to the interests of developers, speculators, financiers, and the 
forces of the market, the mass of the population was left with a sense of loss and dispossession (Harvey 85). As a result of Haussmann's renovation of Paris many old neighborhoods were demolished, resulting in the displacement of many impoverished communities. Although problems of overcrowding, inadequate constructions for the poor, and a geographic outlay that reinforced social stratification were not phenomena particular to this historical era, these issues intensified throughout this time of redevelopment and gained renewed attention.

For Baudelaire overcrowding became a topic of interest as he developed a fascination with flanerie, a style of urban spectatorship in vogue throughout the era. In Paris as Revolution, Priscilla Parkhurst Ferguson goes beyond offering a static definition of the flâneur by historicizing the term. Through readings of various nineteenth-century authors, Ferguson explains how the role of the flâneur shifted over the course of the nineteenth century. She argues that urban narratives of the flâneur transformed from "discourses of placement" to "discourses of displacement," as flâneur-writers who possessed an intrinsic surety of their relationship to Paris of the early nineteenth-century became overwhelmed by the very processes of change that had once seemed so exhilarating after the 1848 Revolution (113). Changing sociopolitical circumstances necessitated new modes of how writers deal with the city.

In "Les Foules," the twelfth prose poem in Baudelaire's 1869 posthumous collection Le Spleen de Paris, the poet admires the intoxicating effect of Parisian crowds: "Celui-là qui épouse facilement la foule connaît des jouissances fiévreuses, dont seront éternellement privés l'égoïste, fermé comme un coffre, et le paresseux, interné comme un mollusque" (35). Baudelaire's poetic narrator describes the feverish delights of crowds as accessible only to spectators who enter the multitude with a receptive disposition. Baudelaire's use of the term fiévreuses merits attention since it refers both to a generic name for a group of diseases which involve an abnormally high body temperature, and it also carries the connotation of being in a state of nervous excitement. The instability of this sensation induced by the multitude calls to mind Walter Benjamin's assertion that for flaneurs such as Baudelaire, "the crowd is not only the newest asylum of outlaws; it is also the latest narcotic for people who have been abandoned" (55). Due to the ambiguity of the term fiévreuses it is implied that crowds stimulate physiological sensations that could be perilous or pleasurable. The uncertainty implies a risk involved in the pursuit of such physiological responses. Unlike the lazy, closed-off people who confine themselves like mollusks, Baudelaire's fascination with crowds indicates a willingness and ability to fleetingly connect with others. To an extent "Les Foules" revels in the decadence of the evolving cityscape but, at the same time, it also indicates the poet's empathic sensibility towards others. Baudelaire's attentive outlook on his milieu enables him to address the troubles of the city's poor while showing us the insalubrious nature of this 'heightened' experience which is at once exciting, unhealthy — even toxic, deadly — and addictive.

The flaneur-style spectatorship that Baudelaire practiced to create his poetic work involved a protoethnographic approach. Indeed, Les Fleurs du mal and Spleen de Paris are ethnographic texts to the extent that they explore "the experiential and expressive ways places are known, imagined, yearned for, held, remembered, voiced, lived contested and struggled over" (Feld and Basso 11). While it bears mentioning that Baudelaire wrote in a time when many authors sought to bridge the gap between science and literature, since Baudelaire wrote before the birth of anthropological ethnography it would be anachronistic to equate his literary work to the work of a social scientific discipline. ${ }^{6}$ However, it merits acknowledging that Baudelaire's poetic analysis of the decadent overcrowded urban environment, featuring depictions of fever-inducing ambiances and starved children,

6 For theories of novel writing that feature methods of observation inspired by the social sciences, see Émile Zola's Le roman expérimental (1881) and Honoré de Balzac's L'avant-propos de la Comédie humaine (1855). 
coincides with an uptick in scientifically rigorous publications on the issue of public health in France. ${ }^{7}$

\section{Development, Exploitation, Inclusion, and Exclusion}

The ensemble of anti-colonial ethnographic essays which constitute Retour de Guyane critique the settler colonialist ventures of the French Empire and call for the uplift of Guyane. The critical text assumes a radical posturing that is seasoned with sarcastic tension in its call for action. Writing for a readership both in Guyane and in the metropole, Damas oftentimes seems to be advocating from a reformist position, especially in the earlier chapters where he makes suggestions on how the colonial administration may improve public policy. ${ }^{8}$ Yet, subtle irony underlies Damas's writing as he suggests that if one is to colonize, to at least 'do it right.' He challenges French settler colonists by leaving them with two options regarding the question of Guyane: "l'aménager ou l'évacuer" (27). This option of either cleaning up or evacuating is offered, with Damas advocating for the latter, as a result of the exploitative French settlement in Guyane and prisonization of the colony's landscape.

To better understand why the French colonial administration did not allot an adequate amount of resources to Guyane, Damas foregrounds Guyane's foundation as a bagne. In efforts to make up for the loss of colonial territory in Canada the French government devised a plan in 1763 to colonize Guyane in an endeavor known as l'expédition de Kourou. While Kourou is now currently Guyane's fourth largest town, located at the estuary of the Kourou River northwest of Cayenne, a 1764 attempt of its settlement along with the tripartite archipelago Îles $d u$ Salut near its coastline, by volunteer colonists mostly from the regions of Alsace and Lorraine ended in nearly ten thousand disease-related deaths. ${ }^{9}$ Due to this disaster, further aspirations of voluntary settlement in Guyane were hindered. Instead the colony became a settlement used to exile political prisoners in a remote location far from metropolitan France. Undesirables such as "gens sans aveu, sans logis, des petits voleurs, des " paumés » sans domicile fixe, des vagabonds, des malfaiteurs qui avaient, injustice supplémentaire, déjà purgé leur peine dans les prisons de France" made up a significant portion of those sent to Guyane to become forced laborers (Clair et al. 8). According to Damas, Guyane's prison administration was historically incompetent. In efforts to save money and resources French authorities never bothered to create the infrastructure needed to accommodate incarcerated bodies upfront: "Trois cent condamnés constituaient le premier convoi. Rien ne fut fait, au préalable, pour recevoir la cargaison. Aucun camp ne fut installé" (48). Shortly after this first group of incarcerated people was relocated to a region near the capital city of Cayenne, near Montjoly, the population panicked. After authorities isolated the incarcerated people further away from the capital and near Kourou and the Oyapock River, there continued to be issues concerning the desirable standards of hygiene for the condemned. Damas describes the result of the neglect: "l'imprévoyance y fait des morts dont le nombre est terrifiant" (49). Aside from the sheer number of deaths, the death of imprisoned people was also terrifying since bagnards libérés and nonincarcerated inhabitants of the colony were often subjected to equally dangerous living conditions. ${ }^{10}$ This malpractice points to the worthlessness of life attributed to those who were criminalized by the state and, by extension, other "minor members of the French nation" (Wilder 5). One of Damas's main arguments is that the punitive measures carried out against the inmates spills out beyond the confines of the

7 See Barnes 65-104.

8 For "Damas's Critique of Republican Colonialism," see Wilder 217-232.

9 See Pariset 11.

10 After numerous incidents of violence from bagnards évadés, a 10 September 1856 "Pétition du Quartier de Kourou" addressed to prison administrators exemplifies an early community-led campaign for the improvement of already existing carceral enclosures, instead of building new ones. 
prison and becomes exemplary of the administration's general disposition towards the colony's broader nonincarcerated population. This observation anticipates Michel Foucault's description of "le continuum carcéral" which acknowledges the mundane ways in which social institutions dominate, oppress, and control through the appropriation of carceral power (303). Through various forms of governmental neglect Guyane, according to Damas, became the "cul-de-monde" (25).

Outrage pervades Damas's ethnography as he details the substandard living conditions that the French colonists created in Guyane, from the Northern commune of Saint-Laurent-du-Maroni to Cayenne. Instead of writing about the conditions in the Amazon rainforest, as he had originally traveled to Guyane to do, Damas focuses on the urban port cities. Here Damas evaluates the dilapidated infrastructure, which he claims is aesthetically unappealing and ill-suited for the local climate. In the chapter on Cayenne he calls attention to the following:

Il est certain que ses constructions dénotent une absence totale de style. Bâties toutes sur un modèle uniforme, qui ne répond ni aux exigences du climat, ni au décor naturel, elles sont généralement trop basses. Faites en bois, elles auraient pu, à l'exemple de ce qui fait en Floride, à Surinam, être coquettes . . . Il n'en est rien. Le souci d'esthétique semble n'avoir jamais effleuré la plupart des constructeurs. On aura simplement bâti des habitations. (66)

Damas's description of Cayenne's buildings, and their bland uniformity, laments the fact that only temporary practicality motivated their construction instead of enduring aesthetic. To further illustrate the wretched condition of Cayenne, he resorts to comparisons with Florida and Suriname, places which he claims at least have decorative architecture. This comparative gesture is something Damas does on multiple occasions throughout his text so as to assure his readers that the case of Guyane is exceptionally worse than other colonial situations. Failing to take into consideration the climate while constructing buildings results in infrastructural deterioration. And to add insult to injury, for the meager infrastructure that the city of Cayenne is equipped with there is a blatant lack of maintenance and upkeep (Damas 66). Damas interprets his dilapidated surroundings as evidence of an offense towards the Guyanais, as he points out: "Le délabrement des façades soulève quelquefois l'indignation" (66). Although Damas does not use the term, what he points to is environmental racism - "the placement of minority communities in proximity of environmentally hazardous or degraded environments, such as toxic waste, pollution, and urban decay" (T.e.j.a.s). ${ }^{11}$ Damas's ethnographic style is attuned to such manifestations of racism in his environment as he references the make-up of cities, institutions, and infrastructure as sources for his analysis in Retour de Guyane.

Another institution which receives Damas's critical scrutiny is the Leprosy Asylum of l'Acarouany. In a penal colony where France's undesirables are concentrated, the leprosy asylum is the location for the colony's most undesirable. The lack of both infrastructural quality and medical resources supports Damas's argument of how lack "soulève quelquefois l'indignation" (66). Damas describes the asylum as having "bâtiments exécrables" with access to "un médecin qui ne vient plus qu'une fois par mois pour ne rester qu'une journée à peine" (115). The irony of a medical facility with an absence of medical professionals raises the question of the purpose for which the asylum is really intended. Damas describes the patients as having no hopes of being cured from their illnesses: "Indépendamment de leur manque de confort, de leur manque total d'hygiène et de propreté, de la noirceur des murs qui n'ont jamais été repeints, de l'ossature même des constructions tombant de vétusté complète, elles sont aussi la proie des intempéries" (116). With more and more evidence pointing to how ill-equipped the facility

11 For more on environmental racism, see www.tejasbarrios.org/justice/. 
is for helping patients get well, and how well-equipped it is to deteriorate their health, Damas dubs the asylum the "antichambre du tombeau" (115). Making clear the fatal consequences of such neglect, he adds: "on va à l'Acarouany pour y être éliminé, sinon guéri, mais assurément pas pour être nourri" (116). In this supposed health care facility there is no nourishment. Instead of caring for the ill, the facility produces the conditions to expedite their elimination. This blatant disregard for the most vulnerable of human life disgusts Damas and leads him to consider how to survive such hostile conditions.

A fact that emerges from the ethnographic work of Damas is that the various perils faced by the Guyanais are the price that's paid for providing a pleasant sense of security for the French Imperial Nation-State. ${ }^{12}$ The solution for getting rid of social outcasts was involuntary exile from metropolitan France, large-scale deportation to any one of the overseas bagnes and colonial expansion through forced penal labor. As anthropologist Peter Redfield has noted in Space in the Tropics: "The colonial bagne existed in some vague unlocated tropics, and one ocean was as good as another. What mattered was the surreal sense of horror associated with the name-heat and disease, not latitude and longitude" (102). This obfuscatory attribute of what Redfield dubs "the spatial vocabulary of empire" captures the public indifference towards regions where penal colonies were established (102). As various penal codes created towards the end of the nineteenth century resulted in new ways of codifying criminality, and consequently increased the numbers of people deported, the living conditions of those located in the colonial tropics was unappreciated. With newly criminalized people banished from urban to colonial spaces of the French Empire, in the name of defending the 'liberal' way of life, the rise in imprisonment endowed colonial administrators with an arrogant sense of self-importance.

While the prioritization of infrastructural development in Guyane was not evident during Damas's visit, it was much less so during the same time that Hausmannization provided an impetus which sought to create clearer, wider streets, facilitate surveillance and class segregation back in the metropole. Despite the semblance of glamor in the New Paris, Baudelaire eulogized the loss of the Old Paris in his 1857 poem "Le Cygne" from Les Fleurs du mal. Set in the Place du Carrousel near the Louvre, the poem laments the changing city: "Comme je traversais le nouveau Carrousel. / Le vieux Paris n'est plus (la forme d'une ville / Change plus vite, hélas ! que le cœur d'un mortel)." As the city changes at a pace the human heart has trouble keeping up with, Baudelaire's poetic voice is filled with what has been dubbed "the imperative of a contemporary nostalgic: to be homesick and to be sick of being at home at the same time" (Boym). The speed with which urban redevelopment is occurring seems inhuman. To illustrate his disdain for the new city, the main symbolic image of "Le Cygne" becomes the spectacle of an attempted escape of a displaced swan in a ménagerie:

Un cygne qui s'était évadé de sa cage,

Et, de ses pieds palmés frottant le pavé sec,

Sur le sol raboteux traînait son blanc plumage.

Près d'un ruisseau sans eau la bête ouvrant le bec

Baignait nerveusement ses ailes dans la poudre,

Et disait, le cœur plein de son beau lac natal :

« Eau, quand donc pleuvras-tu ? quand tonneras-tu, foudre?»

Je vois ce malheureux, mythe étrange et fatal. (204)

Anti-carceral imagery is employed as the swan's escape from an enclosure for the exhibition of animals amounts to a poetic critique of the creature's exploitation. Baudelaire highlights the extent to which the swan is out of place as it is unable to find sustenance, searching for water but surrounded by dryness. The sense of displacement is active on

12 I borrow this term from Wilder (2005). 
several registers as Baudelaire's swan experiences encagement and is transplanted to a parched urban space. Harsh imagery of webbed feet chaffing against dry pavement and feathers dragging on the ground demonstrates the painfulness of the situation. The forlorn waterfowl is reminiscent of another one of Baudelaire's prose-poems featuring a seabird, "L'albatros," whose "ailes de géant l'empêchent de marcher" (39). Whereas the albatross serves to symbolize the poet and centers "the bird's alienation in the everyday world and the ridicule it provokes among the people ignorant of and unmoved by its transcendent calling," it has been postulated that Baudelaire's "swan is but a historical palimpsest for the dodo bird" (Walton 82; Lionnet 82).

Providing crucial geographically specific context for "Le Cygne" in "Reframing Baudelaire," Françoise Lionnet points out the extent to which Baudelaire's trip to the Indian Ocean islands in his youth may have informed his thematization of the bird by explaining: "In the course of its colonial history, Mauritius was briefly settled by the Portuguese, who called the island Ilha do Cirne, or Island of the Swan" (81). The island's name, as Lionnet explains, was attributed to colonial encounters with the indigenous dodo birds, a now extinct creature which resembled a short-winged swan. This unusual and flightless bird made such a lasting impact that the main newspaper of the island echoed this Lusophone misnomer: as it was called Le cerneen (from cirne, swan) and had a picture of a swan on its front page (Lionnet 81). Lionnet hypothesizes that there is a high probability that the poet encountered this newspaper "and that his choice of poetic imagery would later echo these experiences" (81). This rigorous geographic contextualization of the poem supports the claim that the swan/dodo bird is "an embellished version of the indigenous fauna," while contending that "the instability of this referent further points to the hybrid local identities of the colonial subjects" (Lionnet 82). This context adds a significant layer of meaning to the creature's explosive call, upon its failure to find any water source, which Baudelaire's narrator interprets as signaling a desire to return to its native lake. The anthropomorphic gesture of interpreting the meaning of the swan/dodo bird's cry indicates the cross-species solidarity felt by the narrator towards the captive creature.

For Baudelaire the condition of the swan becomes a metaphor for displacement. In the second part of the poem Baudelaire uses the swan as a segue to discuss the exiled condition of other persons. The animal becomes a polysemous symbol:

Je pense à la négresse, amaigrie et phtisique

Piétinant dans la boue, et cherchant, l'œil hagard,

Les cocotiers absents de la superbe Afrique

Derrière la muraille immense du brouillard ;. . ./

Je pense aux matelots oubliés dans une île,

Aux captifs, aux vaincus ! . . à bien d'autres encor !

From a négresse, to sailors on deserted islands, captives and the vanquished alike, the animal's condition is shown to be similar to that of marginalized humans. The image of the négresse seeking coconut trees, which Baudelaire associates with a superb Africa, in the urban landscape mimics the swan's hopeless search for water. The wall of mist that the négresse encounters, which clouds her vision, serves as a climatic impediment to reinforce the sensation of displacement established by the prose-poem's opening imagery of a transforming cityscape. Once again, Lionnet's interpretation serves to foreground local histories over continental frameworks that easily gloss over Baudelaire's rhetoric of exoticism without accounting for the ways in which he in fact "suggests a negation of tropical exoticism" (727). As she details: "Baudelaire's reference to the disappearance of the island's flora," the "images of scattered "phantoms" of tropical trees, the "cocotiers," evoke "a world that has already begun to be savaged by the monoculture of sugarcane" (Lionnet 727). The line "Les cocotiers absents de la superbe Afrique," a phrase that also appears in Baudealire's poem "À une malabaraise” (1866), “conjures a (hypothetically) 
transplanted woman's dreams of an absent land" while also "metonymically [connoting] the actual disappearance of the ebony forests and the extinction of indigenous animals such as the dodo" (Baudelaire Line 47; Lionnet 727, 734). Lionnet's reading of "Le Cygne" considers how biographical details of Baudelaire's 1841 trip to islands of Mauritius and Bourbon, should inform our reading of imagery such as absent palm trees and the négresse. ${ }^{13}$ It merits noting that the prose-poem's final line, "Aux captifs, aux vaincus ! [...] à bien d'autres encor!," reiterates carceral imagery that evokes an environment shaped by oppressive dynamics such as "le continuum carcéral" (Baudelaire Line 56; Foucault 303). Considering "Le Cygne's" investment in "the elevation of the abject," the thematic suitability of the poem's dedication becomes more evident since it is dedicated to Victor Hugo, creator of the figure Jean Valjean, the archetypal noble convict (Walton 79).

The discourse of displacement in Baudelaire's poetry is intimately tied to the increasingly alienating decadence of the urban environment. Consequently, his prosepoems examine how beings living in degraded environments cope with the difficulties presented with destitute conditions. The poet views the New Paris as a facade that represses underlying issues of poverty and marginalization, or as Ann-Louise Shapiro calls it "an illusion which belied the reality" (32). While the new buildings of Paris may seem to be adorned with "tout l'or du pauvre monde," such lavish infrastructure does little to alleviate the sense of ostracism for the city's poor (84 Baudelaire). In fact, the blatant display of wealth in public space exacerbates the exclusionary attributes of the cityscape.

\section{Conclusion: "l'ivresse du pouvoir absolu"}

In the most recent comprehensive English-language monograph that critically surveys Damas's oeuvre, F. Bart Miller briefly connects Baudelaire and Damas through one central theme they share: intoxication, which serves as both poetic device and reoccurring image. As the author of Les Paradis artificiels (1860), Baudelaire is often associated with documenting accounts of drug-induced visions and physiological responses. Meanwhile in the poetry of Damas, most notably in Black-Label (1956), drunkenness is thematized through an intoxicated narrator. Although a focus on the most common and obvious human intoxicant-alcohol-sets up Miller's poetic comparison between the two authors, the thematic overlap between the authors also encompasses a broader meaning of intoxication.

Beyond mere drunkenness, intoxication is a useful physiological metaphor for describing social activities that induce effects which oscillate between pleasure and peril. Broadening intoxication as a category of analysis, beyond simply a matter of consuming alcohol, is something Baudelaire's poetry encourages. As he commands readers to "get drunk" in his Spleen de Paris poem "Enivrez-vous" (1864), he complicates the affair for readers with the following question: "Mais de quoi ? De vin, de poésie ou de vertu, a votre guise. Mais enivrez-vous" (Baudelaire 168). In the context of alcohol intoxication, the 'buzz' of a couple of drinks is often considered to be a pleasant sensation in the course of a casual social event, while the unpleasant hangover-as well as its attendant fever, dehydration, and headaches - is a well-known peril of excessive drinking. In this vein, the metaphor of intoxication evident in the works of Damas and Baudelaire operates in their respective settings to highlight how "luxury consumption creates a sense of social alienation" (Richards 173). For instance, while the affluent woman who demands that the restaurant waiter dismiss the poor family gazing at her table in "Les yeux des pauvres" is partaking in the Parisian pleasure of a fine dining experience at a grand boulevard, her ability to dismiss undesirables indicates a level of power that could be intoxicating in and of itself. The peril of her dehumanizing behavior is that "one cannot deny the humanity of

13 For more on Baudelaire's trip to the Indian Ocean, see Laver xxiii-xxxvi; Lionnet (1998, 66-68); and Lionnet (2008, 724). 
another without diminishing one's own" (Baldwin 66). To further extend this metaphor in the context of Guyane, gold mining is often perceived as a source of pleasure since the extraction of mineral resources is often accompanied by the promise of prosperity. Yet, when finite resources are mined at the expense of destroying the ecosystem on which local communities depend for their livelihoods the peril of such activity becomes evident. Tying together the excess associated with intoxication and the arbitrary abuse of colonial administrative power in Retour, Damas describes the violent temperament of a colonial cadet by the name of Adalbert de la Revardière, one of the first functionaries to be in control in the colony, as being under: "l'ivresse du pouvoir absolu" (32).

Both Damas and Baudelaire point towards the carceral attributes of urban and colonial modernity for the displaced and marginal, which are invisibilized by liberal indifference and bourgeois callousness. By adopting scopic regimes that inform their critical modes of perception, flânerie and ethnography, they are able to work across genres to offer social commentary through artistic practice. The paradigm of pleasure and peril offers intellectual space to make an interpretive leap towards a poetics of colonial society's intoxication. May future studies of Léon Damas take up this generative route of interpretation so as to contribute towards a growing field of comparative scholarship that places Damas in conversation with other critical literary figures.

The University of Texas at Austin

\section{WORKS CITED}

Aldrich, Robert. "Imperial Mise En Valeur and Mise En Scène: Recent Works on French Colonialism." The Historical Journal, vol.45, no.4, Dec. 2002, pp. 917-936.

Baldwin, James. "Fifth Avenue, Uptown." Nobody Knows My Name. New York: Dell, 1961, pp. 55-66.

Baudelaire, Charles. Le Spleen de Paris : Petits poèmes en prose. 1869. Ed. Jean-Luc Steinmetz. Paris : Le Livre de Poche, 2003.

—. Les Fleurs du mal. 1857. Paris : Éditions Collins, 1922.

Barnes. David S. "The Sanitarians' Legacy, of How Health Became Public." The Great Stink of Paris and the Nineteenth-Century Struggle against Filth and Germs. Baltimore: John Hopkins University Press, 2006, pp. 65-104.

Benjamin, Walter. "The Flâneur." Charles Baudelaire: A lyric Poet in the Era of High Capitalism. Trans. Harry Zohn. London / New York: Verso, 1997, p. 85

Bernal, Dolores Delgado, et al. "Chicana/Latina Testimonios: Mapping the Methodological, Pedagogical, and Political," Equity \& Excellence in Education, vol. 45 , no. 3, 2012, pp. 363-372.

Boym, Svetlana. "Nostalgia." Atlas of Transformation. http://monumenttotransformation.org/atlas-oftransformation $/ \mathrm{html} / \mathrm{n} /$ nostalgia/nostalgia-svetlana-boym.

Clair, Sylvie, et al. "Introduction." Établissements pénitentiaires coloniaux, 1792-1952, Série Colonies H: Répertoire Numérique. Paris : Archives nationales, 1990, pp. 7-14.

Damas, Léon-Gontran. Retour de Guyane, Suivi de Misère Noire, et autres écrits journalistiques. 1938. Paris : Jean-Michel Place, 2003.

- Damas, Léon-Gontran. "La Négritude en question." Interview by Jeune Afrique. Critical Perspectives on Léon-Gontran Damas. Ed. Keith Q. Warner. Washington, DC: Three Continents Press, 1988, p. 15.

Davis, Mike. "Haussmann in the Tropics." Planet of Slums. New York: Verso, 2006, pp. 95-120. 
Debaene, Vincent. "Les écrivains contre l'ethnologie ? Ethnographie, ethnologie et littérature d'Afrique et des Antilles, 1921-1948." Romanic Review, vol. 104, no. 3-4, 2013, pp. 353-374.

Djiropo, Richard. "L'expression du « moi » comme une synecdoque du nègre : je, cet autre toi, mon frère nègre, chez Damas." Léon-Gontran Damas : Poète, écrivain patrimonial et postcolonial. Matoury : Ibis Rouge, 2014, pp. 131-138.

Feld, Steven and Keith H. Basso, editors. "Introduction." Senses of Place. Santa Fe: School of American Research Press, 1996, pp. 3-12

Ferguson, Priscilla Parkhurst. "The Flâneur: The City and Its Discontents." Paris as Revolution: Writing the Nineteenth-Century City. Berkeley: University of California Press, 1994, pp. 80-114.

Foucault, Michel. "Le carcéral." Punir et surveiller : Naissance de la prison. Paris : Gallimard, 1975, pp. 300-315.

Gyssels, Kathleen. "Léon-Gontran Damas et le mythe de l'Amérindien," Dalhousie French Studies, vol. 86, Spring 2009, pp. 45-56.

-. "Introduction." Black Label ou les déboires de Léon-Gontran Damas. Paris: Passage(s), 2016, pp.13-20.

—. "Léon-Gontran Damas." 13 Sept. 2003, http://ile-en-ile.org/damas/.

Harvey, David. "The Organization of Space Relations." Paris Capital of Modernity. London / New York: Routledge, 2003, pp. 117-124.

Hochman, Brian. "Introduction." Savage Preservation: The Ethnographic Origins of Modern Media Technology. Minneapolis: University of Minnesota Press, 2014, pp. ixxxvii.

Jenks, Chris and Tiago Neves. "A Walk on the Wild Side: Urban Ethnography Meets the Flâneur." Cultural Values, vol. 4, no.1, 2000, pp. 1-17.

Jeune Afrique. "La Négritude en question." Critical Perspectives on Léon-Gontran Damas. Ed. Keith Q. Warner. Washington DC: Three Continents Press, 1988.

Kellman, Jordan. "Beyond center and Periphery: New Currents in French and Francophone Atlantic Studies." Atlantic Studies, vol. 10, no. 1, pp. 1-11.

Lionnet, Françoise. "Reframing Baudelaire: Literary History, Biography, Postcolonial Theory and Vernacular Language" Diacritics, vol. 28, no. 3, 1998, pp. 62-85.

—. "“The Indies': Baudelaire's Colonial World.” $P M L A$, vol.123, no. 3, 2008, pp. 723736.

Laver, James. "Introduction.” Flowers of Evil. New York: The Heritage Press, 1971. xxiiixxxvi.

Miller, F. Bart. "Damas's Confrontation with Colonialism: Ethnographic Essaysism and Anti-Colonial Critique in Retour de Guyane." Rethinking Négritude through LéonGontran Damas. Amsterdam : Rodopi, 2014, pp. 103-144.

Pariset, André-Aimé. Note sur la colonisation blanche à la Guyane française. 5 April 1851. Imprimerie Nationale, May 1851. Box H 20. Archives nationales d'outre-mer, Aix-enProvence, France. 20 June 2017.

Pels, Peter. "After Objectivity an Historical Approach to the Intersubjective in Ethnography." Journal of Ethnographic Theory, vol. 4, no. 1, 2014, pp. 211-236.

"Pétition du Quartier de Kourou." 10 September 1856. Box H 14. Archives nationales d'outre-mer, Aix-en-Provence, France. Accessed 20 June 2017.

Redfield, Peter. Space in the Tropics: From to Rockets in French Guiana. Berkeley / Los Angeles: University of California Press, 2000.

Richards, Donald G. "Towards a Virtuous Public Finance." Economics, Ethics, and Ancient Thought: Towards a Virtuous Public Policy. London / New York: Routledge, 2017, p. 160-177.

Sanchez, Jean-Lucien. "Les 'incorrigibles' du bagne colonial de Guyane. Genèse et application d'une catégorie pénale.” Genèses, vol. 91, no. 2, 2013, pp. 71-95. 
Shapiro, Ann-Louise. Housing the Poor of Paris, 1850-1902. Madison: University of Wisconsin Press, 1985.

Soukup, Charles. "The Postmodern Ethnographic Flaneur and the Study of HyperMediated Everyday Life." Journal of Contemporary Ethnography, vol.42, no. 2, p. 226-254.

Taubira-Delannon, Christiane. "La situation du secteur aurifère en Guyane." L'or en Guyane : Eclats et artifices. Paris : La Documentation Française, 2000, pp. 15-25.

Texas Environmental Justice Advocacy Services (T.e.j.a.s). "Environmental Justice." T.e.j.a.s www.tejasbarrios.org/justice/.

Walton, Stephen. "Baudelaire and the Roots of 'Négritude." Dalhousie French Studies, Vol. 39/40, Summer/Fall 1997, pp. 77-88.

Wilder, Gary. "Cultural Nationalism." The French Imperial Nation-State: Négritude and Colonial Humanism between the Two World Wars. Chicago: University of Chicago Press, 2005, pp. 201-255.

Wood, Sarah and Catriona MacLeod. "Introduction." Locating Guyane. Liverpool: Liverpool University Press, 2018, pp. 1-14.

Wright, Gordon. "The Republican Experiment, 1848-1852." France in Modern Times: From Enlightenment to Present. $4^{\text {th }}$ ed., New York / London: Norton, 1987, pp.129141.

Vizenor, Gerald. "Aesthetics of Survivance." Survivance: Narrative on Native Resistance. Lincoln: University of Nebraska Press, 2008, pp. 1-24. 